\title{
Implementasi Pengenalan Jenis Pola Tapak Ban (Tread) Menggunakan Metode Local Binary Patterns
}

\author{
Ambrosius Sitompul \\ Program Studi Teknik Informatika, STMIK Budi Darma, Medan, Indonesia \\ Email: ambrosiussitompul@gmail.com
}

\begin{abstract}
Abstrak-Pesatnya Perkembangan dalam bidang teknologi saat ini membuat segala urusan menjadi lebih mudah salah satunya dalam bidang pengolahan citra, pengolahan citra menjadi sebuah trend dalami bidang komunikasi multimedia termasuk indutri otomotif. Dengan melakukan pengolahan citra kita bisa memanfaaatkank informasi yang terkandung di dalam sebuah cuplikan citra. Dalam penelitian ini memanfaatkan teknologi pengolahan citra digital untuk pengenalan dari setiap jenis ban, kondisi ban merupakan salah satu aspek penting dari standar kelayakan mobil, dan standar yang ada di Indonesia dan saat ini sedikit terabaikan,hal ini disinyalir menjadi salah satu penyebab kecelakaan di Indonesia. Saat ini sistem uji kelayakan ban yang ada dilakukan dengan memanfaatkan tenaga manusia akan tetapi manusia memiliki keterbatasan.
\end{abstract}

Kata Kunci: Tapak Ban, Local Binary Patterns.

Abstract-The rapid development in the field of technology now makes matters easier, one of which is in the field of image processing, image processing has become a trend in the field of multimedia communication including the automotive industry. By doing image processing we can use the information contained in an image snapshot. In this study utilizing digital image processing technology for the introduction of each type of tire, tire condition is one of the important aspects of car eligibility standards, and standards that exist in Indonesia and are currently a bit neglected, this is thought to be one of the causes of accidents in Indonesia. Currently the existing tire feasibility test system is carried out by utilizing human power but humans have limitations.

Keywords: Tire Tread, Local Binary Patterns

\section{PENDAHULUAN}

Perkembangan dalam bidang teknologi saat ini menempatkan pengolahan citra sebagai trend dari sebuah teknologi di bidang komunikasi multimedia termasuk indutri otomotif. Dengan melakukan pengolahan citra kita bisa menarik informasi yang terkandung di dalam sebuah cuplikan citra. Dalam penelitian ini memanfaatkan teknologi pengolahan citra digital untuk mendeteksi keausan ban, kondisi ban merupakan salah satu aspek penting dari standar kelayakan jalan dari sebuah ban mobil yang ada di Indonesia dan saat ini sedikit terabaikan,hal ini disinyalir menjadi salah satu penyebab kecelakaan di Indonesia. Saat ini sistem uji kelayakan ban yang ada dilakukan dengan memanfaatkan tenaga manusia akan tetapi manusia memiliki keterbatasan.

Pada penelitian ini menggunakan metode Local Binary Patterns yang merupakan metode yang mudah dan efisien untuk mendapatkan karakteristik citra ban yaitu motif permukaan dan kedalaman ban, Local Binary Patterns (LBP) didefinisikan sebagai perbandingan nilai biner piksel pada pusat citra dengan 8 nilai piksel disekelilingnya dengan begitu dapat dicocokkan citra 4uji dengan citra acuan[1].

Pada Penelitian sebelumnya dapat menciptakan sebuah sistem dengan metode Local Binary Patterns yang dapat menghasilkan output berupa kondisi kelayakan sebuah ban dari mobil yang tentunya memiliki tingkat akurasi yang tinggi hal ini dapat dibuktikan dengan akurasi data uji tertinggi yang didapat oleh sistem ini yaitu $91,82 \%[2]$.

\section{METODE PENELITIAN}

\subsection{Tapak Ban}

Ban adalah salah satu komponen yang sangat penting, karena berhubungan langsung dengan aspal jalanan. Pada komponen itulah keselamatan, pengendalian, akselerasi, pengereman dan berapa luas area tapak ban yang menempel pada jalan akan memberikan keamanan pada pengendara yang memiliki fungsi sebagai berikut:

1. Untuk memikul beban kendaraan

2. Meredam kejutan-kejutan yang ditimbulkan oleh keadaan permukaan jalan

3. Mencegah kejutan-kejutan yang ditimbulkan berpindah ke body atau rumah-rumah kendaraan

Ban pun terdiri dari 3 struktur yang memiliki fungsi masing masing yaitu:

1. Carcass (Bengkarak), fungsinya menahan berat, goncangan, tumbukan dan tekanan angin.

2. Tread (Telapak), berfungsi melindungi carcass dari keausan dan kerusakan kerusakan lainnya.

3. Breaker, berfungsi sebagai bantalan untuk meredam goncangan serta mengurangi perubahanelastisitas Ban memiliki 2 jenis yaitu ban Radial dan Ban bias seperti gambar berikut: 


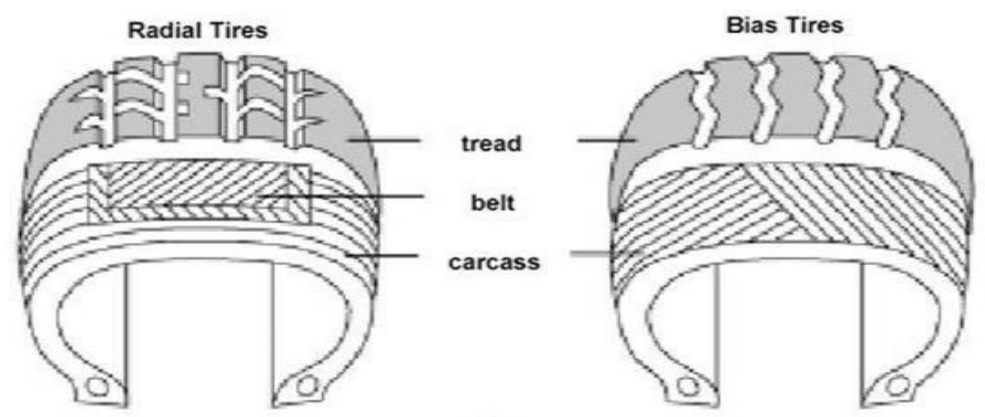

Gambar 1. Perbedaaan Ban bias dan Ban radial.

\subsection{Metode Local Binary Patterns}

LBP adalah metode analisis tekstur yang menggunakan model statistika dan struktur [7]. LBP pertama kali diperkenalkan oleh Timo Ojala. Operator LBP menggunakan perbandingan nilai keabuan dari piksel-piksel ketetanggaan. Operator dasar LBP berukuran 3 x 3 menggunakan 8 piksel ketetanggan in dari sebuah piksel tengah ic. Piksel ketetanggaan ke-n tersebut di-threshold menggunakan nilai keabuan dari piksel tengah seperti yang ditunjukkan pada persamaan (1) dan fungsi thresholding $\mathrm{s}(\mathrm{x})$ seperti yang ditunjukkan pada persamaan (2). Kode binary hasil operator LBP piksel ketetanggaan akan digunakan untuk merepresentasikan fitur dari piksel tengah ic.

$$
\begin{aligned}
& \operatorname{LBP}\left(x_{c}, y_{c}\right)=\sum_{n=0}^{7} s\left(i_{n}-i_{c}\right) 2^{n} \\
& s(x)=\left\{\begin{array}{l}
1, \text { if } x \geq 0 \\
0, \text { if } x<0
\end{array}\right.
\end{aligned}
$$

Ilustrasi dari proses LBP.yaitu proses pertama adalah melakukan pengurangan piksel ketetanggaan dengan piksel tengah (1). Selanjutnya hasil pengurangan di-threshold menggunakan persamaan (2), jika hasilnya $\geq 0$ maka diberi nilai 1 dan jika hasilnya $<0$ maka diberi nilai 0 . Setelah itu, nilai biner piksel ketetanggaan akan disusun berlawanan arah jarum jam dan 8 bit biner tersebut dikonversi ke dalam nilai desimal untuk menggantikan nilai piksel tengah ic.

Menurut [6] kelebihan dari LBP adalah mudah diimplementasikan dan tingkat komputasinya lebih rendah sehingga tidak membutuhkan waktu yang lama dalam ekstraksi fitur. Euclidean Distance Euclidean Distance adalah metriks yang paling sering digunakan untuk menghitung kesamaan dari dua vektor dengan menghasilkan nilai yang berupa jarak dari kedua vektor tersebut. Nilai Euclidean Distance diperoleh dari akar kuadrat selisih 2 vektor yang akan dihitung jaraknya. Untuk menghitung nilai Euclidean Distance dari vektor fitur masukan dan vektor fitur pembanding digunakan persamaan.

Algoritma LBP pertama kali dikenalkan oleh Ojala et al,dan telah terbukti sebagai deskriptor tekstur yang tangguh. Algoritma LBP melabeli piksel-piksel dari sebuah citra dengan melakukan proses thresholding ketetanggaan 3x3 dari masing-masing piksel sebagai nilai tengah dan mengubah hasilnya menjadi nilai biner, dan 256-bin LBP histogram digunakan sebagai texture descry ptor. Bilangan biner yang dihasilkan (disebut Local Binary Patterns atau LBP codes) mengkodekan lokal primitif termasuk variasi dari lengkungan sisi, bintik, area datar, dsb. Batasan dari operator dasar LBP (yaitu 3x3 neighborhood tidak dapat menangkap ciri dominan yang memiliki struktur dengan skala besar). Karena itu kemudian operator dikembangkan untuk menggunakan tingkat ketetanggan dengan ukuran yang berbeda. Menggunakan circular neighborhood dan bilinear interpolation nilai piksel memungkinkan beragam ukuran radiusdan jumlah pengambilan titik sampel. Lihat figure 5 untuk contohLBP operator, dimana $(\mathrm{P}, \mathrm{R})$ menunjukkan jumlah pengambilan titik sampel $\mathrm{P}$ dari radius $\mathrm{R}$ dari sebuah circular symmetricneighbor set.

\section{HASIL DAN PEMBAHASAN}

Untuk mengenali suatu pola dari setiap karakteristik ban terhadap berbagai tipe jalan, membutuhkan adanya ciriciri khusus. Seperti jenis-jenis pola tapak ban Pola Rib, Pola Lug, Pola Rib dan Lug dan Pola Blok setiap pola mempunyai ciri-ciri yang berbeda-beda dengan karakter yang lain. Ciri-ciri berguna untuk membedakan antara pola yang satu dengan yang lain. Ciri yang bagus adalah ciri yang memiliki daya pembeda yang tinggi, sehingga pengelompokan pola berdasarkan ciri yang dimiliki dapat menghasilkan keakuratan yang tinggi. Ekstrasi ciri adalah proses pengambilan ciri-ciri dari suatu objek di dalam citra untuk membedakan objek yang satu dengan yang lain. Sebelum dilakukan ekstrasi ciri, biasanya perlu dilakukan benerisasi, thinning, dan normalisasi terlebih dahulu. Dalam penelitian ini digunakan metode ekstrasi ciri dari setiap objek. Penggunaan metode Local Binary 
Patterns untuk menemukan ciri dari setiap objek. Penggunaan metode Local Binary Patterns, karena kebanyakan komponen Tapak ban terdiri dari garis-garis.

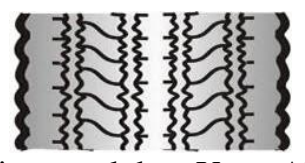

Gambar 2. Contoh Citra tapak ban Yang Akan Dikenali

\subsection{Penerapan Local Binary Patterns Pada Tapak Ban}

Untuk membedakan arah garis tersebut diperlukan suatu pengkodean dari setiap arah garis. Dalam penelitian ini arah garis vertikal dikodekan dengan angka 2, arah garis diagonal kanan dikodekan dengan angka 3, arah garis horizontal dikodekan dengan angka 4 dan arah garis diagonal kiri dikodekan dengan angka 5. Kode-kode tersebut akan menggantikan piksel-piksel hitam dari suatu citra karakter.

Langkah dalam penerapan Local Binary Patterns adalah sebaai berikut :

1. Lakukan pelabelan terhadap data citra yang bukan background.

2. Setelah dilakukan pelabelan terhadap data citra, maka dilakukan perhitungan nilai statistik untuk setiap kode arah dengan rumus :

$\mathrm{K}(\mathrm{n})=\frac{\text { Jumlah piksel dengan kode } \mathrm{n}}{\text { ukuran matriks yang digunakan }}$

Dimana :

$\mathrm{K}=$ kode arah

$\mathrm{n}=$ nomor kode arah

3. Membangun vektor ciri (feature vector) feature yang terdiri dari empat pasangan informasi tentang ada tidaknya piksel dengan kode arah tertentu dan nilai statistiknya.

Untuk memperkuat hasil analisa metode Local Binary Patternsdi atas penulis menyajikan sebuah contoh kasus pengenalan pola tapak bandengan menggunakan metode Local Binary Patterns. Pada contoh kasus ini, akan dikenali sebuah citra digital yang mengandung sebuah pola huruf. Citra digital ini akan dideteksi garis tepinya sehingga menghasilkan sebuah citra digital baru dalam bentuk hitam putihseperti terlihat pada Gambar 3.2. Untuk setiap piksel yang berwarna hitam, akan diberi nilai bobot 1 dan untuk pixel berwarna putih akan diberi nilai bobot 0 . Berdasarkan pemberian nilai bobot tersebut, dihasilkanlah sebuah matriks yang merepresentasikan pembobotan citra digital pada tabel sebagaimana terlihat pada Tabel 1.

Tabel 1. Pembobotan Citra digital

\begin{tabular}{l|llll}
\hline & 1 & 1 & 1 & 1 \\
\hline 1 & 1 & 1 & 1 & 1 \\
1 & 1 & 1 & 1 & 1 \\
1 & 1 & 1 & 1 & 1 \\
1 & 1 & 1 & 1 & 1
\end{tabular}

Hasil pemetaan citra digital dalam bentuk matriks ini kemudian dibagi menjadi beberapa bagian dalam bentuk matriks 8 X 8, seperti terlihat pada tabel 2. sampai 5 .

Tabel 2. Hasil pemetaan citra digital

\begin{tabular}{lllll}
\hline 1 & 1 & 1 & 1 & 1 \\
1 & 1 & 1 & 1 & 1 \\
1 & 1 & 1 & 1 & 1 \\
1 & 1 & 1 & 1 & 1 \\
1 & 1 & 1 & 1 & 1 \\
1 & 1 & 1 & 1 & 1 \\
1 & 1 & 1 & 1 & 1 \\
1 & 1 & 1 & 1 & 1 \\
\hline
\end{tabular}

Tabel 3. Hasil pemetaan citra digital

\begin{tabular}{lllll}
\hline 1 & 1 & 1 & 1 & 1 \\
1 & 1 & 1 & 1 & 1 \\
1 & 1 & 1 & 1 & 1 \\
1 & 1 & 1 & 1 & 1 \\
1 & 1 & 1 & 1 & 1 \\
\hline
\end{tabular}


Tabel 4. Hasil pemetaan citra digital

\begin{tabular}{lllll}
\hline 1 & 1 & 1 & 1 & 1 \\
1 & 1 & 1 & 0 & 0 \\
1 & 1 & 1 & 1 & 1 \\
1 & 1 & 1 & 1 & 1 \\
1 & 1 & 1 & 1 & 1 \\
\hline
\end{tabular}

Tabel 5. Hasil pemetaan citra digital

\begin{tabular}{lllll}
\hline 1 & 1 & 1 & 1 & 1 \\
1 & 1 & 1 & 1 & 1 \\
1 & 1 & 1 & 1 & 1 \\
1 & 1 & 1 & 1 & 1 \\
1 & 1 & 1 & 1 & 1 \\
\hline
\end{tabular}

Untuk hasil pemetaan citra digital dalam bentuk matriks yang tidak memenuhi bentuk matriks $8 \mathrm{X} 8$, hasil pemetaan dibentuk ke dalam matriks sesuai dengan ukuran pemetaannya, sebagaimana terlihat pada tabel 6 . sampai tabel 10 .

Tabel 6. Hasil pemetaan citra digital

\begin{tabular}{lllll}
\hline 1 & 1 & 1 & 1 & 1 \\
1 & 1 & 1 & 1 & 1 \\
1 & 1 & 1 & 1 & 1 \\
1 & 1 & 1 & 1 & 1 \\
\hline
\end{tabular}

Tabel 7. Hasil pemetaan citra digital

\begin{tabular}{rrrrr}
\hline 1 & \multicolumn{1}{r}{1} & \multicolumn{1}{c}{1} & \multicolumn{1}{r}{1} & 1 \\
1 & 1 & 1 & 1 & 1 \\
1 & 1 & 1 & 1 & 1 \\
1 & 1 & 1 & 1 & 1 \\
\hline
\end{tabular}

Tabel 8. Hasil pemetaan citra digital

\begin{tabular}{llll}
\hline 1 & 1 & 1 & 1 \\
1 & 1 & 1 & 1 \\
1 & 1 & 1 & 1 \\
1 & 1 & 1 & 1 \\
\hline
\end{tabular}

Tabel 9. Hasil pemetaan citra digital

\begin{tabular}{llll}
\hline 1 & 1 & 1 & 1 \\
1 & 1 & 1 & 1 \\
1 & 1 & 1 & 1 \\
1 & 1 & 1 & 1 \\
\hline
\end{tabular}

Tabel 10. Hasil pemetaan citra digital

\begin{tabular}{llll}
\hline & 1 & 1 & 1 \\
1 & 1 & 1 & 1 \\
1 & 1 & 1 & 1 \\
1 & 1 & 1 & 1 \\
\hline
\end{tabular}

Dari hasil bentuk matriks yang ditunjukkan pada gambar akan dilakukan inisialisasi bobot nilai awal untuk setiap matriks dengan menggunakan rumus :

Dimana :

$$
\mathrm{F}(\mathrm{x})=\mathrm{f}\left(\sum \mathrm{X}_{\mathrm{i}} * \mathrm{~W}_{\mathrm{i}}\right)
$$

$\mathrm{F}(\mathrm{x})=$ Bobot nilai awal

$\mathrm{X}_{\mathrm{i}} \quad=\quad$ Nilai 0 pada matriks

$\mathrm{W}_{\mathrm{i}} \quad=$ Jumlah data pada matriks

Sehingga, untuk matriks pertama diperoleh bobot nilai awal :

$\mathrm{F}(1)=(0 * 64)=0$

Untuk matriks kedua diperoleh bobot nilai awal :

$\mathrm{F}(2)=(0 * 64)=0$

Untuk matriks ketiga diperoleh bobot nilai awal : 
$\mathrm{F}(3)=(10 * 64)=640$

Untuk matriks keempat diperoleh bobot nilai awal :

$\mathrm{F}(4)=(1 * 64)=64$

Untuk matriks kelima diperoleh bobot nilai awal :

$\mathrm{F}(5)=(0 * 32)=0$

Untuk matriks keenam diperoleh bobot nilai awal :

$\mathrm{F}(6)=(0 * 32)=0$

Untuk matriks ketujuh diperoleh bobot nilai awal :

$\mathrm{F}(7)=(0 * 32)=0$

Untuk matriks kedelapan diperoleh bobot nilai awal :

$\mathrm{F}(8)=(0 * 32)=0$

Untuk matriks kesembilan diperoleh bobot nilai awal :

$\mathrm{F}(9)=(0 * 16)=0$

Selanjutnya, dicari besar faktor skala yang akan digunakan dalam pengenalan karakter dengan menggunakan rumus :

Di mana :

$$
\beta=0.7(\mathrm{p})^{1 / \mathrm{n}}
$$

$\beta=$ Faktor skala

$\mathrm{p}=$ Jumlah nilai 0 pada hasil pemetaan matriks

$\mathrm{n} \quad=$ Jumlah data pada hasil pemetaan matriks

Sehingga untuk faktor skala dari hasil pemetaan matriks diatas adalah :
$\beta=0.7(11)^{1 / 400}=$
$0.7 * 36,36363=25,45454$

Selanjutnya, akan ditentukan arah vektor untuk masing-masing bobot nilai awal matriks berdasarkan output yang dinginkan. Misalnya, ditentukan nilai outputnya adalah 0 dan diatas 0 , maka hasil penentuan arah vektor untuk masing-masing seperti terlihat pada Gambar 4.

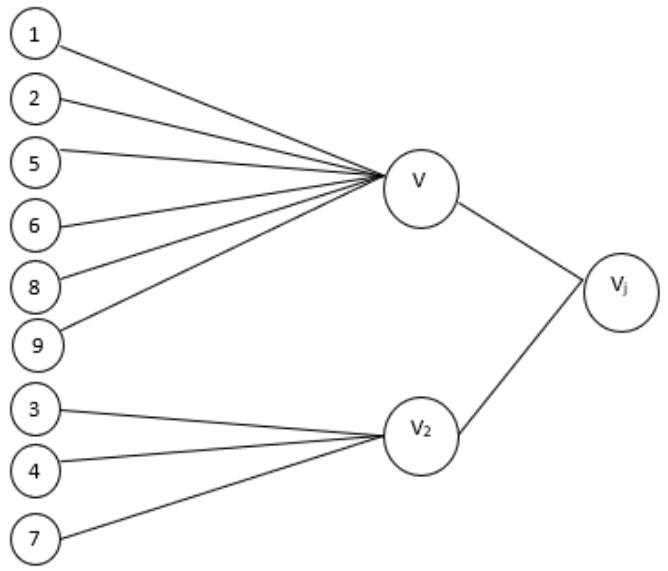

Gambar 3. Penentuan Arah Pola

Langkah terakhir, akan dihitung nilai output dari pembentukan arah pola yaitu :

$$
\begin{aligned}
\mathrm{V}_{\mathrm{j}} & =\frac{\beta^{*}\left(V_{1}+V_{2}\right)}{\text { Jumlah Data }}=\frac{25,45454 *(0+2944)}{400}=\frac{2969,45454}{400} \\
& =7,4236363
\end{aligned}
$$

Nilai $\mathrm{V}_{\mathrm{j}}$ inilah yang nantinya akan dibandingkan dengan nilai pola.

\subsection{Implementasi}

Perancangan Aplikasi pengenalan jenis pola tapak ban telah dirancang dan dibuat dengan menggunakan Tools Visualbasic.Net 2008. Tampilan Program ini terdiri dari Tampilan Input, Proses dan Output.

1. Hasil pengenalan jenis pola tapak ban pola rib

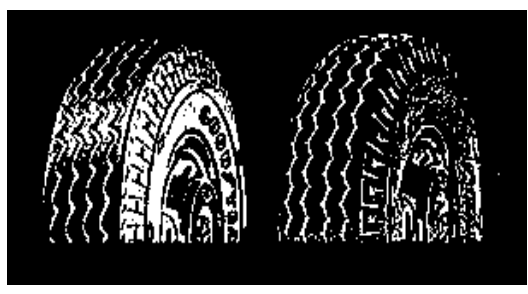

Gambar 4. hasil pengenalan jenis pola rib 
2. Hasil Pengenalan jenis pola lug

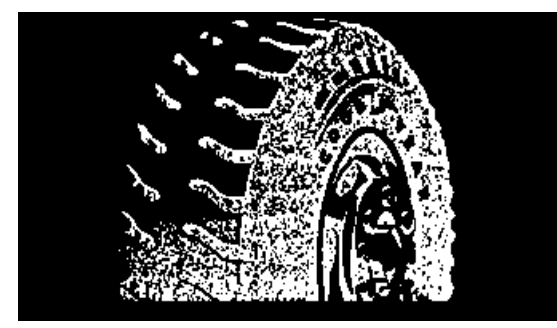

Gambar 5. Hasil pengenalan jenis pola lug

3. Hasil Pengenalan jenis pola Rib dan Lug

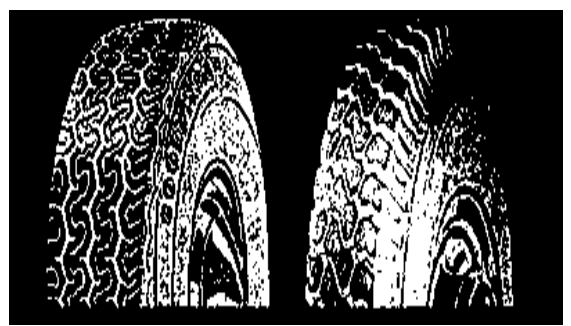

Gambar 6. Hasil pengenalan jenis pola Rib dan lug

4 Hasil Pengenalan jenis pola Block

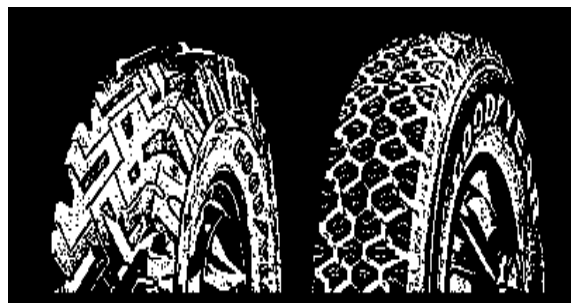

Gambar 7. Hasil pengenalan jenis pola Block.

\section{KESIMPULAN}

Melalui penelitian yang telah dilakukan penulis pada Implementasi Pengenalan jenis pola tapak ban (TREAD) menggunakan metode Local Binary Patterns, maka dapat disimpulkan :

1. Sistem yang dirancang dengan metode LBP dapat digunakan untuk mengenali jenis pola pada tapak ban dengan tingkat akurasi tertinggi $91,82 \%$.

2. Penerapan Metode Local Binary Patterns dapat digunakan pada pengenalan jenis pola tapak ban sebagai salah satu tujuan untuk mempercepat proses pengenalan pola.

3. Hasil Perancangan Aplikasi Pengenalan jenis pola tapak ban (TREAD) adalah mengetahui jenis pola yang cocok dengan karakteristik jalan.

\section{REFERENCES}

[1] U. A. Dahlan, "SEGMENTASI CITRA BATIK BERDASARKAN FITUR TEKSTUR MENGGUNAKAN METODE FILTER GABOR DAN K -MEANS CLUSTERING,” vol. 10, no. 1, pp. 1173-1179, 2016.

[2] A. Nurjati, R. Magdalena, and I. N. A. Ramatryana, "DETEKSI KERUSAKAN PERMUKAAN BAN PADA ANGKUTAN UMUM DENGAN METODE LOCAL BINARY PATTERN DAN KLASIFIKASI NEAREST NEIGHBOR,” vol. 3, no. 2, pp. 1986-1993, 2016.

[3] Sutoyo. T. dan e. a. , Teori Pengolahan Citra Digital, Yogyakarta : ANDI \& UDINUS, 2009

[4] P. Darma, Pengolahan Citra Digital. Yogyakarta: Andi, 2010.

[5] E. Prasetyo, Pengolahan Citra Digital dan Aplikasinya menggunakan Matlab. Yogyakarta: Andi, 2011.

[6] S. Aripin, G. L. Ginting, and N. Silalahi, "Penerapan metode retinex untuk meningkatkan kecerahan citra pada hasil screenshot," Media Inform. Budidarma, vol. 1, no. 1, pp. 24-27, 2017. 